\title{
Development of Performance Management System The Bureucracy of Local Government
}

\author{
Andriyus \\ Islamic University of Riau \\ Pekanbaru, Indonesia \\ Email: andriyus@soc.uir.ac.id
}

\begin{abstract}
Government bureaucracy is a system for organizing government organizations in order to manifest the management of activities and the implementation of a policy that is efficient, rational, and effective. Therefore the Government's bureaucratic organization is required to be able to achieve good performance and meets the principle of accountability. In order to achieve good performance and accountability, government bureaucracy will need to develop a performance management system that is integrated, so that each implementation activity and Government policy be optimized so that the vision and mission of the Organization the Government was able to be achieved as a set. To be able to develop an effective performance management system on the Organization of government bureaucracy, some necessary requirements include: (a) the existence of the relevance of factors measured by the object (her work) or measuring instruments used are valid and reliable in the performance assessment; (b) the direction is sensitive to differences in performance of employees, and conducted assessment of personal and group; (c) Model and the performance management system operationalization that is applied can be well understood by all parties involved in it; and (d) use the standard/objective objective benchmarks or not in favour of (subjective) in the performance appraisal system, applying the suggestions and feedback is good, and the good communication between the parties involved in the management system performance; (e) bringing together human approach work - the result to be achieved are hard-wired with a good fit with the model system as well as technical devices; and (f) the importance of the principle of "learning organization" to be combined with the concept of performance management is applied.
\end{abstract}

Keywords: performance management, government bureaucracy

\section{INTRODUCTION}

Along with the rapid pace of globalization today, then any organization good government organizations as well as private organizations, must be able to run any operational activities effectively and efficiently so that the organization is able to face the challenge of change and the development of increasingly advanced ages. For that, each organization is required to be able to display a high level of performance through the development of management performance systematically, especially in government organizations.
Performance is the description of the level of achievement of results from implementation an activity or policy. The Government's bureaucratic organization as an organization that hosts a variety of Governmental Affairs, development, and empowerment, then performance achievement is very important, because of a good organizational performance and be more accountable guarantee the quality of the implementation of the policy. Therefore, government organizations need to manage performance, both regarding the human resources of the Organization as well as various support facilities, by developing and implementing a performance management system for government organizations and effectively, both on the Central Government or local governments.

The development of a performance management system at the Government's bureaucratic organization is one of the programs and activities of the strengthening of performance accountability in the framework of the implementation of the reform of the bureaucracy, as defined in regulation Minister Utilization of State apparatus and the reform of the Bureaucracy of the Republic of Indonesia number 11 Year 2011 about the criteria and the measure of the success of the reform of the bureaucracy, in order to build a system that is capable of pushing a measurable organizational performance. Through the system in an effort to approach the development of your organization's performance management system of the Government bureaucracy then it can be expected that the performance of human resources will be optimized and reached Government the accountable organization performance. With such vision and mission of the Organization of the Government which has yet materialized.

\section{DISCUSSION}

\section{A. Organization and Government Bureaucracy}

The organization is a container that allows the community can achieve results that previously could not be reached by the individual themselves. The organization is a coordinated unit, which consists of at least two people, serves reached one particular goal or set of goals (Rivai, 2006; 189) organization currently has grown so rapidly, either private organization's profit-oriented or public organization which hosts a Government and public service. As the Organization of large- 
scale public/government organizations then needs to apply a bureaucratic organization in order for the vision and mission of the Organization are achieved as defined.

According to Weber in the Santosa (2009; 3), each activity that demands strict coordination against the activities of a large number of people and involves specialized skills, so the only chance is to lift or use bureaucratic with the organization. The reason it is important to develop the Organization, always bureaucratic with based solely on technical advantage compared to other organizational forms.

According to Thoha $(2009 ; 15)$, bureaucracy is a system to organize a large organization in order to be obtained in order for the efficient management of acquired, rational, and effective. Furthermore, according to Weber in Thoha (2009; 47), a rational bureaucracy ideal type was done in the following ways:

1) Individual officials are personal freedom but limited by his Office while he was running the tasks or interests of an individual in his position. Officials not to use his position for his own personal needs and interests include his family.

2) Offices that are arranged in a hierarchy of levels from top to bottom and sideways. Consequently, there is the Office of superiors and subordinates, and some are wielding more power and are smaller.

3) The duties and functions of each Office in the hierarchy that are specifically different from each other.

4) Every contract has a term of officials should be run. Description of tasks (job description) each officer, is the domain becomes the authority and responsibility that must be run in accordance with the contract.

5) Each of the officials is selected on the basis of his professional qualifications, ideally, this is done through a competitive exam.

6) Each officer has a paycheck including the right to receive a pension in accordance with the hierarchical level of an office he carried. Each of the officials could decide to quit the job and his position in accordance with his wishes and his contract could be terminated under certain circumstances.

7) There is a clear career development structure with promotions based on seniority and merit corresponds to an objective consideration.

8) Every officer is in no way justified his post and run another instance resources for personal gain and his family.

9) Every officer is under the control and supervision of a system which is run in the discipline.

Gerald Caiden in Thoha (2012; 57), stated that the work of government organizations that cannot be avoided by humans. The characteristic of the activities of the organization or Government bureaucracy it searches through niche-niche of human life. This trait that distinguishes between the organization governments bureaucracies with non-government organizations including the Organization of a company. It's just a typical feature of these at once monopolies that made the exhibit inevitably people should be satisfied with the service of the Government bureaucracy. It doesn't matter whether it's fast or slow service, satisfying or obnoxious, appreciate the human's or don't care to men who served. The behavior of the bureaucratic system that is indeed very concerned about impersonal nature.

Next Max Weber in Thoha (2012; 57), stating that the system is called bureaucracy that does not know the personal behavior, very formal, and according to the procedural order. Weberian bureaucratic behavior was always oriented to legalistic etatisme. Hence a bureaucratic approach embraced by many of the procedural order of Government that is based on rules or regulatory nature that cannot be abandoned.

\section{B. Organizational Performance}

Simply put, Rue \& Byars in Ali $(2012 ; 212)$, declared the results of the achievement level of performance as the degree of accomplishment category ". In other words, performance is the level of achievement of the objectives of the organization. In this sense, to what extent refers to a performance goal that has been set is able to be achieved by the organization.

Meanwhile, according to Bastian in Ali (2012; 213), "performance is a reflection of the level of achievement of the implementation of an activity/program/wisdom in realizing the objectives, goals, mission, and vision of the Organization contained in the formulation of the scheme strategies an organization ". Of the definition reflected clearly the intent and purpose of performance, including evaluation and accountability. This means that the performance is not final, but the process is cyclical and sustainable so that its existence into something that is very important for the Organization's leaders in taking policy and improve the quality of the implementation of the policy.

Indicators of organizational performance is the size of the quantitative and qualitative level of achievement that illustrates the objectives or purposes set out taking into account the elements of the following indicators: (Batian in Tangkilisan, 2005; 175)

1) Input Indicators (inputs), i.e. everything that is needed in order that the Organization was able to produce the products, goods or services, which include human resources, information, policy, and so on.

2) Output Indicators (outputs), that is something to be expected right out of an activity in the form of physical or nonphysical.

3) Indicator results (outcomes), i.e. everything which reflects the proper functioning of the activities on the medium-term output (direct effect).

4) Indicators of benefit (benefit), which is something related to the ultimate goal of the implementation activities. 
5) Indicators of impacts (impacts), which influence posed, both positive and negative, on every level indicators based on assumptions that have been set.

\section{Performance Management System}

Performance management (performance management) in principle involve all aspects of the work achievements of an organization. It should include the whole effort improving the means - infrastructure - the process or method of work the ability of human resources follow the passion and motivation it works - quality of raw material and other supporting elements. In practice, because it's so complex, usually more emphasized on an improvement of employee accomplishments (managing performance employee's) (Ruky in Ibrahim, 2009; 78).

Performance management approach has evolved from centering on an individual (individual-centered approach) based on the job (job-centered approach to centers on the results (objective centered approach) (Putti in Ibrahim, 2009; 78). In his statement, performance management is good, should adopt the approach system with model input process - output; so the third approach mentioned above with a variety of its interaction with the environment can be managed in an integrated and holistic in nature, therefore we recommend is called performance management system (Ibrahim, 2009; 79)

The performance management system will run effectively if it fulfilled a variety of terms including (Ibrahim, 2009; 79)

a. There is relevance between factors measured by the object (her work) or the instrument is valid and reliable.

b. Sensitive to performance differences, so that the assessment is not average (meaning there are personal and group assessment).

c. Model and operationalizes systems can be well understood by all parties involved in it.

d. Performance management systems are less successful, if standards/benchmarks are not objective, the judgment in favor of (subjective), System suggestions and feedback that is less good, less good and communication between the parties involved in the management system such performance.

e. In a brief review of performance management system as empowering the Organization essentially systematic, encompassing human performance improvement efforts and support facilities. With the focus performance improvement though, the nature of this system should not be ignored, especially bringing together human approach - work - the result to be achieved must be programmed properly, in accordance with the model of the system as well as technical devices appropriate anyway. In fact, many of the performance improvement programs that have been implemented (for example for the bureaucracy) but impressed as the program off, no/less systematic nature, so often the results the results of performance improvement of personnel not many influential towards the improvement of products and services.

f. Look also the importance of the principle of "learning organization": needs to be combined with the concept of performance management, it means an increase in the performance of human resources (employees) would be more maximum results with reciprocity empowerment group/unit so it can be quickly utilized for the improvement of organizational performance/public administration.

\section{CONCLUSION}

From the description put forth then it can be inferred that the systems approach is needed in government bureaucracy organization performance management so that the performance of the Government organizations able to optimally achieved and accountable, so that the vision and mission of the Organization the Government has set can be realized. To be able to develop an effective performance management system on the Organization of government bureaucracy, some necessary requirements include: (a) the existence of the relevance of between factors measured by the object (her work) or measuring instruments used are valid and reliable in the performance assessment; (b) the direction is sensitive to differences in performance of employees and conducted assessment of personal and group; (c) Model and the performance management system operationalization that is applied can be well understood by all parties involved in it; (d) use the standard/benchmark objective or not in favour of (subjective) in the performance appraisal system, applying the suggestions and feedback is good, and the good communication between the parties involved in the performance management system; (e) bringing together human approach - work - the result to be achieved are hardwired with a good fit with the model system as well as technical devices and (f) the importance of the principle of "learning organization" to be combined with the concept of performance management is applied. 


\section{REFERENCES}

[1] Ali, Eko Maulana, Kepemimpinan Transformasional dalam Birokrasi Pemerintahan, Cetakan Pertama, Jakarta, PT. Multicerdas Publishing, 2012

[2] Ibrahim, Amin, Pokok-poko Administrasi Publik dan Implementasinya, Cetakan Kedua, Bandung, Refika Aditama, 2009.

[3] Rivai, Veitzal, Kepemimpinan dan Perilaku Organisasi, Edisi Kedua, Jakarta, PT. RajaGrafindo Persada. 2006.

[4] Santosa, Panji, Administrasi Publik: Teori dan Aplikasi Good Governance, Cetakan Kedua, Bandung, Refika Aditama, 2009.

[5] Tangkilisan, H.N.S, Manajemen Publik, Jakarta: Grasindo. 2005.

[6] Thoha, Miftah, Birokrasi Pemerintah Indonesia di Era Reformasi, Cetakan Kedua, Jakarta, Kencana, 2009.

[7] Thoha, Miftah, Birokrasi Pemerintah dan Kekuasaan di Indonesia, Cetakan I, Yogyakarta, Matapena Institute, 2012.

[8] Peraturah Menteri Pendayagunaan Aparatur Negara dan Reformasi Birokrasi RI Nomor 11 Tahun 2011 Tentang Kriteria dan Ukuran Keberhasilam Reformasi Birokrasi. 